\title{
PERAN STRES KERJA MEMEDIASI PENGARUH BEBAN KERJA TERHADAP BURNOUT PERAWAT RUMAH SAKIT DAERAH MANGUSADA BADUNG
}

\author{
Putu Meliantha Kusumawati ${ }^{1}$ \\ I Gusti Ayu Manuati Dewi $^{2}$
}

\begin{abstract}
Fakultas Ekonomi dan Bisnis, Universitas Udayana, Bali, Indonesia email:melianthakusuma33@gmail.com
\end{abstract}

\begin{abstract}
ABSTRAK
Kondisi seseorang ketika mengalami kelelahan fisik, mental, maupun emosional disebut burnout. Penelitian ini bertujuan untuk mengukur tingkat burnout yang dipengaruhi oleh beban kerja dan dimediasi stres kerja. Lokasi penelitian terletak di Rumah Sakit Daerah (RSD) Mangusada Badung khususnya di Ruang Oleg dengan jumlah sampel sebanyak 50 perawat dengan metode penentuan sampel jenuh. Teknik pengumpulan data dengan menggunakan sistem wawancara dan penyebaran. Analisis jalur, uji sobel, dan uji VAF digunakan sebagai alat analisis data dalam penelitian ini. Hasil penelitian menunjukkan bahwa beban kerja dan stres kerja masing-masing berpengaruh positif dan signifikan terhadap burnout dan stres kerja secara parsial memediasi pengaruh beban kerja terhadap burnout. Penelitian ini juga memberikan pemahaman bahwa beban kerja dan stres kerja dapat berpengaruh signifikan terhadap burnout, ketika perawat merasakan beban kerja yang berlebih maka stres kerja juga akan meningkat sehingga berpotensi meningkatkan timbulnya burnout.
\end{abstract}

Kata kunci: Burnout; Beban kerja; Stres Kerja

\section{ABSTRACT}

A person's condition when experiencing physical, mental, or emotional exhaustion is called burnout. This study aims to measure the level of burnout which is influenced by workload and is mediated by work stress. The research location is located at the Regional Hospital (RSD) Mangusada Badung, especially in the Oleg Room with a total sample of 50 nurses with the saturation sampling method. Data collection techniques using interview and dissemination systems. The type of data analysis used was path analysis and single test. The results showed that workload and work stress each had a positive and significant effect on burnout and work stress partially mediated the effect of workload on burnout. This study also provides an understanding that workload and work stress can have a significant effect on burnout, when the workload perceived by nurses is higher, the work stress felt by nurses will be higher so that it has the potential to increase burnout.

Keywords: Burnout; Workload; Job Stress 


\section{PENDAHULUAN}

Istilah burnout digunakan untuk menunjukkan suatu jenis stres kerja yang dicetuskan pertama kali pada tahun 1974 oleh Herbert Freudenberger dalam jurnal psikologi profesional (Pradana et al., 2017). Penelitian oleh (Gnerre et al., 2017) menjelaskan burnout merupakan suatu sindrom yang diawali dengan gejala kelelahan fisik dan mental yang ekstrim. Variabel ini ditunjukkan dengan beberapa perubahan sikap maupun perilaku sebagai reaksi menarik diri dari pekerjaan seperti menjaga jarak, bersikap sinis, membolos, sering terlambat kerja, sampai memiliki keinginan yang kuat untuk pindah kerja (Rubab, 2017). Kurangnya keinginan dan rasa tertarik individu terhadap pekerjaan yang dilakukan menunjukkan pemicu munculnya burnout yang diakibatkan oleh tekanan atau beban kerja yang (Fajriani \& Septiari, 2015). Hasil ini sejalan dengan studi yang dilakukan Pradana et al. (2017) yang menjelaskan beban kerja berpengaruh terhadap kejadian burnout.

Kondisi dimana seseorang mengalami kelelahan fisik, mental dan emosional yang nantinya akan berdampak pada munculnya depersonalisasi dan rendahnya prestasi diri pada seseorang juga merupakan definisi dari burnout (Pradana et al., 2017). Kondisi ini disebabkan karena pekerjaan yang terlalu berat, sehingga menyebabkan menurunnya produktivitas karyawan, kurangnya konsentrasi selama bekerja, kehadiran yang kurang, dan beban pikiran yang mengganggu kinerja. Kelelahan kerja (burnout) mengacu pada saat sumber daya dan kemampuan yang dibutuhkan tidak lagi memadai untuk memenuhi persyaratan pekerjaan (Lan et al., 2018). Seseorang tidak memiliki minat dan ketertarikan terhadap pekerjaan yang dilakukannya, hal ini menekankan penyebab terjadinya burnout karena tekanan atau beban pekerjaan yang besar (Fajriani \& Septiari, 2015). Hal ini juga ditemukan dalam penelitian Pradana et al. (2017) yang menjelaskan bahwa beban kerja memiliki pengaruh terhadap timbulnya burnout. Dijelaskan lebih lanjut dalam penelitian Dewi \& Riana, (2019) bahwa beban kerja memiliki pengaruh yang positif dan signifikan terhadap burnout.

Beban kerja dapat didefinisikan sebagai jumlah kegiatan yang harus diselesaikan oleh seseorang atau sekelompok orang selama periode waktu tertentu dalam keadaan normal. Beban kerja sebagai proses untuk menetapkan jumlah jam kerja yang digunakan atau dibutuhkan untuk merampungkan suatu pekerjaan dalam waktu tertentu, apabila hal ini berlebihan maka terjadi burnout (Atmaja \& Suana, 2018). Hal ini juga didukung dengan hasil penelitian Wijaya \& Wibawa, (2020) yang menjelaskan adanya beban kerja yang berlebihan memberikan pengaruh positif terhadap burnout. Beban kerja dapat diartikan sebagai banyaknya kegiatan yang harus diselesaikan oleh seseorang atau sekelompok orang selama kurun waktu tertentu dalam keadaan normal (Fajriani \& Septiari, 2015). Dalam mengukur tingkat beban kerja yang dirasakan seseorang, proporsi waktu kerja yang dibebankan kepada perawat dalam menyelesaikan pekerjaannya haruslah seimbang, jika berlebihan maka terjadi burnout (Atmaja \& Suana, 2018). Masalah beban kerja dan stres kerja berpengaruh terhadap tingkat burnout yang dialami seseorang (Ziaei et al., 2015). Stres kerja memiliki hubungan dengan meningkatnya tuntutan beban pekerjaan (Atmaja \& Suana, 2018). Stres kerja berkepanjangan dengan kondisi emosional yang tidak stabil dan secara tidak langsung akan memicu terjadinya burnout (Fajriani \& Septiari, 2015). Banyak penelitian telah menunjukkan 
bahwa stres kerja secara langsung mempengaruhi burnout (Chiang \& Liu, 2017).

Semua jenis stres pada dasarnya disebabkan oleh kurangnya pemahaman seseorang terhadap kapabilitas diri masing-masing. Ketika seseorang kurang mengetahui kapabilitasnya maka hal ini yang memicu terjadinya gejala-gejala yang berkaitan dengan stres kerja (Widyastuti, 2015). Stres kerja dapat didefinisikan sebagai tuntutan pekerjaan yang melebihi kemampuan seseorang dalam jangka waktu yang lama, dengan paparan kerja yang berlebihan diluar kemampuan individu dapat mengakibatkan ketidakberdayaan dan akhirnya menimbulkan sindrom kelelahan kerja atau burnout (Koc \& Bozkurt, 2017). Stres yang berkepanjangan dapat memperburuk kondisi emosional, fisik, dan mental perawat, yang kemudian dapat mengakibatkan kelelahan fisik dan mental karena terkurasnya energi untuk menghadapi stres yang terus-menerus. Stres kerja yang terjadi secara terus-menerus dengan intensitas yang tinggi dapat menyebabkan terjadinya burnout (Dewi \& Riana, 2019).

Penelitian Pradana et al. (2017) menjelaskan mengenai tingkat burnout di Eropa, yang menunjukan 43 persen burnout dialami pekerja pelayanan kesehatan dan sosial (perawat), 32 persen dialami guru, dan sisanya didominasi oleh pekerja administrasi dan manajemen, serta bidang hukum dan kepolisian. Rumah sakit sebagai salah satu fasilitas pelayanan kesehatan merupakan bagian dari sumber daya kesehatan yang sangat diperlukan dalam rangka mendukung penyelenggaraan upaya kesehatan, begitu pula dengan Rumah Sakit Daerah (RSD) Mangusada Badung. Sebagai jasa pelayanan kesehatan RSD Mangusada Badung dituntut untuk memberikan pelayanan terbaiknya bagi masyarakat, dari kinerja berbagai lapisan staff serta tenaga medis harus menunjukkan kemampuan yang optimal dalam melayani masyarakat maupun menangani setiap keluhan pasien. Namun dalam melaksanakan tugas, khususnya tenaga medis yakni perawat, dihadapkan pada berbagai beban dan tantangan dalam bekerja yang tak jarang menimbulkan kejenuhan dan kelelahan kerja yang akan menimbulkan turunnya kualitas pelayanan. Menurunnya kualitas pelayanan bukan hanya karena faktor menurunnya kemampuan tenaga kerja, melainkan karena tingginya beban kerja yang berakibat perawat menjadi letih secara fisik dan mental (Eliyana, 2016). Perubahan sosial baru-baru ini mungkin telah berkontribusi pada peningkatan kelelahan dalam profesi kesehatan, dimana kelelahan kerja di antara profesional tenaga kesehatan adalah masalah serius dan semakin meningkat (Kumar, 2018). Hasil penelitian Wati dkk. (2016) menjelaskan perawat sering mengalami tekanan untuk menyelesaikan pekerjaannya. Kondisi tersebut sama halnya dengan masalah yang dihadapi oleh perawat di RSD Mangusada Badung, khususnya di Ruang Oleg. Hasil wawancara dengan Kepala Bidang Pengembangan dan Penelitian RSD Mangusada Badung, menjelaskan bahwa Ruang Oleg merupakan ruangan dengan tingkat tekanan kerja yang tinggi. 
Tabel 1.

Jumlah Perawat dan Pasien Ruang Oleg RSD Mangusada Badung

\begin{tabular}{cccccccc}
\hline \multicolumn{2}{c}{ Th. 2017} & \multicolumn{2}{c}{ Th. 2018 } & \multicolumn{2}{c}{ Th. 2019 } & \multicolumn{2}{c}{ Th. 2020 } \\
\hline Perawat & Pasien & Perawat & Pasien & Perawat & Pasien & Perawat & Pasien \\
\hline 42 & 3053 & 43 & 3341 & 43 & 3918 & 50 & 1934 \\
\hline
\end{tabular}

Sumber:RSD Mangusada, 2020

Tabel 1. menunjukkan jumlah pasien di Ruang Oleg RSD Mangusada Badung meningkat tiap tahunnya, sehingga intensitas pekerjaan juga akan meningkat. Namun jumlah perawat hanya berkisar 40-50 orang, sedangkan menurut standar Manajemen Penugasan Klinik Perawat (MPKP) menjelaskan satu orang perawat hanya boleh menangangi 6-8 orang pasien. Hal tersebut menunjukkan jumlah pasien dan perawat tidak sebanding. Jumlah pasien yang membludak dapat memicu beban pekerjaan yang berlebih sehingga membuat perawat kewalahan dalam menangani pasien. Ruang Oleg per tanggal 1 Juli 2020 juga ditetapkan menjadi ruangan untuk penanganan pasien Covid-19. Tentunya kondisi ini semakin menambah tekanan bagi perawat karena jumlah perawat tidak dilakukan penambahan. Kondisi ini secara tidak langsung akan memicu terjadinya stres.

Dari data hasil pra survei dan wawancara dengan Kepala Ruang Oleg, dapat disimpulkan bahwa terdapat masalah burnout yang tinggi pada perawat Ruang Oleg RSD Mangusada Badung. Penelitian ini secara empiris bertujuan untuk menguji peran stres kerja dalam memediasi pengaruh beban kerja terhadap burnout pada perawat di Ruang Oleg RSD Mangusada Badung. Berdasarkan latar belakang diatas maka dapat dirumuskan permasalahan sebagai berikut; 1) Bagaimana pengaruh beban kerja terhadap stres kerja? 2) Bagaimana beban kerja memengaruhi burnout? 3) Bagaimana stres kerja mempengaruhi burnout? 4) Apa peran mediasi stres kerja terhadap pengaruh beban kerja terhadap burnout?

Adapun landasan teori yang digunakan sebagai acuan pada penelitian ini adalah Teori Atribusi (Attribution Theory) yang membahas tentang upaya untuk memahami penyebab perilaku seseorang. Dikembangkan oleh Fritz Heider pada Tahun 1958, teori ini menjelaskan penyebab perilaku individu dan orang lain yang ditentukan oleh faktor internal misalnya sifat, karakter, sikap, ataupun faktor eksternal misalnya tekanan situasi atau keadaan tertentu yang akan memberikan pengaruh terhadap perilaku yang bersangkutan (Robbins, 2008). Teori ini diarahkan untuk mengembangkan penjelasan dengan cara-cara kita menilai orang secara berlainan, tergantung makna apa yang akan kita hubungkan (atribusikan) ke suatu perilaku tertentu. Penelitian Dewi \& Riana, (2019) menyatakan bahwa kekuatan internal atau yang dikenal dengan istilah atribusi personal meliputi kemampuan, usaha dan kelelahan, sedangkan kekuatan eksternal atau atribusi lingkungan meliputi aturan, tekanan, dan cuaca. Kedua kekuatan ini bersama-sama menentukan perilaku manusia. Atribusi internal maupun eksternal dinyatakan dapat mempengaruhi produktivitas, kualitas, kepuasan kerja, dan kinerja seseorang, yang pada akhirnya berpengaruh pada sikap dan perilaku seseorang (Pesireron, 2016). Hal ini pula yang terjadi ketika seseorang mengalami kelelahan kerja atau yang sering disebut dengan istilah burnout.

Burnout merupakan kelelahan fisik, mental, dan emosional yang terjadi 
karena stres yang diderita dalam jangka waktu yang lama dan melibatkan emosional yang tinggi. Kelelahan akan memengaruhi produktivitas, kualitas, kepuasan kerja, dan kinerja. Burnout dapat terjadi kepada seorang karyawan ketika kondisi emosionalnya tidak stabil dan stres yang dialami karyawan tersebut berkepanjangan. Karyawan tersebut menjadi tidak memiliki minat dan ketertarikan terhadap pekerjaan yang dilakukannya. Penyebab terjadinya burnout pada karyawan adalah karena tekanan atau beban pekerjaan yang besar, sehingga karyawan merasa tidak senang dan nyaman dalam menyelesaikan pekerjaannya. Seseorang mengalami gejala burnout antara lain ada rasa gagal dalam diri, cepat marah dan sering jengkel, sering merasa bersalah dan disalahkan, keengganan dan ketidakberdayaan, menjadi negatif dan ditarik, merasa lelah dan kelelahan setiap hari, hilangnya perasaan positif terhadap klien, menunda kontak dengan klien dan membatasi ponsel dari klien, sinis dan sering menyalahkan klien, sering sulit untuk tidur bahkan untuk menggunakan obat penenang, menghindari diskusi pekerjaan dengan rekan kerja, sering masuk angin dan flu, sakit kepala dan gangguan pencernaan, kurang luwes berpikir dan kurang tahan terhadap perubahan, ketidakpercayaan berlebihan, paranoid, dan konflik pernikahan atau keluarga berkepanjangan.

Beban kerja dapat diartikan sebagai suatu perbedaan antara kemampuan seseorang dengan tuntutan pekerjaan yang harus dihadapi, dimana pekerjaan manusia memiliki tingkat pembebanan yang berbeda-beda. Beban pekerjaan didasarkan pada pemanfaatan waktu kerja yang tersedia untuk melakukan pekerjaan, yaitu dilihat dari aktivitas, atau kegiatan yang dilakukan staf pada waktu kerja, baik kegiatan langsung, tidak langsung, dan kegiatan lain seperti kegiatan pribadi dan kegiatan tidak produktif. Beban pekerjaan dapat didefinisikan sebagai jumlah kegiatan yang harus diselesaikan oleh seseorang atau sekelompok orang selama periode waktu tertentu dalam keadaan normal. Beban kerja adalah tuntutan pekerjaan yang dipunyai sehari-hari dan dianggap sebagai sumber beban. Adapun beban kerja disini dapat dibedakan pengertiannya menjadi dua, yaitu beban kerja yang berlebihan (overload) dan beban kerja yang di bawah rata-rata (underload). Beban kerja merupakan sesuatu yang muncul dari interaksi antara tuntutan tugas yang diberikan, lingkungan kerja, keterampilan, perilaku, dan persepsi pekerja. Sehingga untuk mencapai beban kerja normal dalam arti volume pekerjaan yang sesuai dengan kemampuan kerja cukup sulit, yang menyebabkan terjadinya ketidakseimbangan meskipun penyimpangannnya kecil.

Stres kerja adalah suatu kondisi dimana individu mengalami ketegangan emosional atau perasaan tertekan baik secara fisik maupun psikologis dalam menghadapi tugas pekerjaan dalam lingkungan kerja yang mampu menghambat kemampuan seseorang. Stres adalah suatu kondisi dinamis dimana seorang individu dihadapkan pada peluang, tuntutan, atau sumber daya yang terkait dengan apa yang dihasratkan oleh individu itu dan yang hasilnya dipandang tidak pasti dan penting. Peran stres kerja sebagai kejadian simultan dari dua atau lebih bentuk tekanan pada tempat kerja, dimana pemenuhan dari satu peran membuat pemenuhan terhadap peran lainnya yang lebih sulit untuk dilaksanakan. Artinya apabila karyawan mengalami stres ditempat kerja, di saat itu seseorang karyawan dalam melaksanakan satu peran tertentu akan merasa kesulitan untuk memenuhi harapan 
peran yang lain. Peran stres kerja ini cenderung makin meningkat ketika tuntutan beban pekerjaan sebagai tanggung jawab yang harus dilaksanakan. Oleh karena itu, tingkat stres kerja setiap orang cenderung berbeda terkait beban pekerjaan yang dirasakan dan peran yang dialaminya.

Segala macam stres pada dasarnya disebabkan oleh kurangnya pemahaman manusia akan keterbatasannya sendiri. Seringkali beban kerja yang berlebih diluar kemampuan seseorang menyebabkan timbulnya kecemasan, perasaan tertekan, dan selalu merasa bersalah terhadap sesuatu yang terjadi, bahkan sampai mengakibatkan gangguan metabolisme pada tubuh (Widyastuti, 2015). Kondisi ini membuat seseorang menjadi tidak tertarik dan tertarik dengan pekerjaan yang dilakukannya. Kecemasan merupakan penyebab stres kerja pada diri seseorang akibat hantaman proporsi kerja yang berlebih, sehingga seseorang kurang menikmati dan kurang optimal dalam menyelesaikan pekerjaan (Fajriani \& Septiari, 2015). Hal ini juga didukung oleh penelitian Atmaja \& Suana, (2018) yang membuktikan bahwa beban kerja berpengaruh positif dan signifikan terhadap stres kerja. Hasil penelitian Melati dkk. (2015) dan Dewi \& Riana, (2019) juga menyatakan hal yang sama.

$\mathrm{H}_{1}$ : beban kerja berpengaruh positif dan signifikan terhadap stres kerja.

Masalah beban kerja memiliki dampak pada tingkat burnout (kelelahan kerja) yang dialami seseorang. Apabila seseorang mengerjakan beban kerja yang berlebih dan mulai menunjukkan rasa bosan dan jenuh terhadap pekerjaan yang sama tiap harinya, selalu dituntut memberikan pelayanan yang berkualitas, dan dituntut bekerja dalam kondisi apapun, membuat seseorang sampai pada tahap kelelahan kerja, atau yang dikenal dengan burnout. Permasalahan ini tentu saja menjadi pemicu terjadinya burnout. Hal ini juga didukung oleh penelitian Pradana dkk., (2017), Fajriani \& Septiari, (2015), (Atmaja \& Suana, 2018), dan (Dewi \& Riana, 2019). Seseorang memerlukan fisik dan mental yang kuat dalam mengerjakan tuntutan beban pekerjaan. Tingkat keberhasilan seseorang dalam menyelesaikan pekerjaan juga dilihat dari berbagai faktor, dengan kemampuan, beban kerja, dan waktu yang diberikan juga sesuai maka seseorang tidak akan merasa tertekan. Sebaliknya, ketika seseorang menyelesaikan pekerjaan diluar kemampuannya serta waktu yang diberikan juga tidak cukup maka akan menimbulkan tekanan. Perasaan tertekan yang dialami secara berkepanjangan tentu membuat seseorang merasa lelah secara emosional, frustrasi terhadap pekerjaannya, mulai kehilangan energi, dan kurang tenang dalam menghadapi pekerjaan. Kondisi inilah yang menyebabkan timbulnya burnout.

$\mathrm{H}_{2}$ : beban kerja berpengaruh positif dan signifikan terhadap burnout.

Kondisi seseorang merasa tidak cocok dengan pekerjaan, mudah tersinggung, tertekan dengan pekerjaan yang bervariasi, ada keinginan untuk pindah kerja, dan mengalami gangguan tidur, maka kondisi ini mengakibatkan ketidakberdayaan seseorang dan akhirnya menimbulkan sindrom kelelahan kerja atau yang disebut juga burnout (Koc \& Bozkurt, 2017). Hal ini juga didukung dengan penelitian Saputro dkk. (2020), Candra \& Huda, (2018), Moch, (2014) yang menjelaskan pengaruh positif dan signifikan stres kerja terhadap burnout. Hal inilah yang melatarbelakangi pengaruh antara stres kerja terhadap burnout. Setiap individu memiliki kemampuan masing-masing dalam bekerja, apabila individu bekerja diluar kemampuan tentu perasaan tertekan akan muncul. Ketika seseorang mulai 
merasa tertekan maka ia merasa gelisah, lelah dan lemah setelah bekerja setiap hari. Kondisi ini perlahan-lahan akan membuat seseorang tidak bahagia berada di tempat kerja dan memiliki keinginan untuk pindah tempat kerja. Hal tersebut merupakan pemicu timbulnya burnout pada seseorang. Hal inilah yang melatarbelakangi pengaruh antara stres kerja terhadap burnout.

$\mathrm{H}_{3}$ : stres kerja berpengaruh positif dan signifikan terhadap burnout.

Stres kerja menunjukkan pengaruh mediasi beban kerja terhadap burnout, dimana pengaruh ini menggambarkan ketika seseorang merasa bosan mengerjakan pekerjaan yang sama setiap harinya, dituntut selalu siap bekerja dalam kondisi apapun, dan merasa jenuh, maka seseorang mengalami masalah pada beban kerja yang berlebihan (Pradana dkk., 2017). Beban kerja yang tinggi dirasakan oleh seseorang seringkali menimbulkan perasaan tertekan, cemas, merasa tidak cocok dengan pekerjaan, selalu menyalahkan diri sendiri, bahkan sampai menyebabkan gangguan pola tidur. Kondisi ini yang menjadi pemicu timbulnya stres kerja. Apabila seseorang mengalami stres kerja yang berkepanjangan, hingga timbul perasaan frustrasi, lelah fisik maupun emosional, merasa pekerjaannya menguras emosi, dan kurang bersemangat untuk bekerja, maka sikap burnout seseorang dalam bekerja akan muncul. Hasil penelitian Dewi \& Riana, (2019), Atmaja \& Suana, (2018) juga menjelaskan efek mediasi positif stres kerja pada beban kerja terhadap kelelahan kerja (burnout). Beban kerja yang berlebih diluar kemampuan seseorang menyebabkan timbulnya kecemasan, perasaan tertekan bahkan sampai mengakibatkan gangguan metabolisme pada tubuh. Ketika seseorang mulai merasa tertekan maka ia merasa gelisah, lelah dan lemah setelah bekerja setiap hari, sehingga seseorang yang merasakan beban kerja tinggi yang secara langsung menimbulkan stres. Stres yang berkepanjangan secara perlahan-lahan akan membuat seseorang merasa lelah secara emosional, frustrasi terhadap pekerjaannya, mulai kehilangan energi, dan kurang tenang dalam menghadapi pekerjaannya. Kondisi ini menyebabkan terjadinya sikap burnout dalam bekerja.

$\mathrm{H}_{4}$ : peran stres kerja berpengaruh positif dan signifikan memediasi pengaruh beban kerja terhadap burnout.

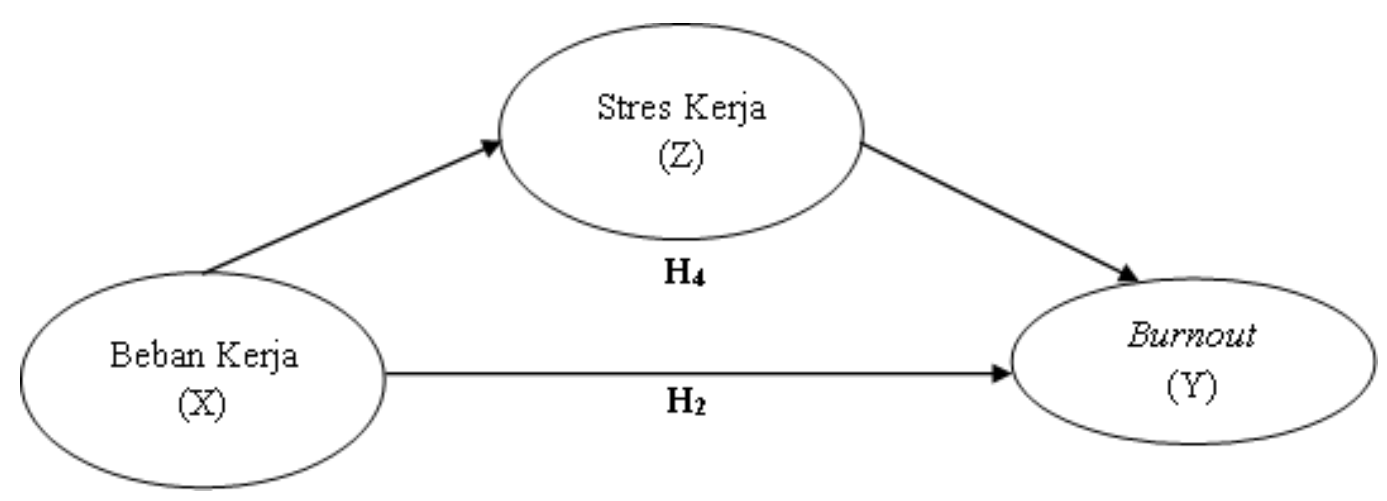

Gambar 1. Kerangka Konseptual 


\section{METODE PENELITIAN}

Metode penelitian yang digunakan tergolong dalam jenis penelitian asosiatif kausalitas. Penelitian asosiatif kausalitas adalah penelitian yang dilakukan untuk menjelaskan pengaruh antara dua variabel atau lebih. Lokasi penelitian ini dilakukan di RSUD Mangusada Badung tepatnya di Ruang Rawat Inap Oleg yang terletak di Jalan Raya Kapal Kecamatan Mengwi Kabupaten Badung. Penelitian ini terdiri dari variabel endogen yaitu burnout (Y) yang merupakan kondisi kelelahan fisik, mental dan emosional perawat di RSD Mangusada Badung. Menurut penelitian Sintyadewi \& Dewi, (2020) burnout terdiri dari tiga indikator yaitu kelelahan emosional (emosional exhaustion), depersonalisasi (depersonalisasi), prestasi pribadi (personal accomplishment). Kelelahan emosional (emotional exhaustion), menggambarkan perasaan emosional yang sangat tinggi dalam pekerjaan ditandai dengan perasaan terkurasnya energi yang dimiliki, berkurangnya sumber-sumber emosional didalam diri seperti rasa kasih, empati dan juga perhatian yang pada akhirnya memunculkan perasaan tidak mampu lagi memberikan pelayanan pada orang lain. Depersonalisasi (depersonalization), menggambarkan respon yang tidak berperasaan dan impersonal terhadap pasien yang dilayani. Pencapaian pribadi (personal accomplishment), menggambarkan rendahnya keyakinan tentang kompetensi dan keberhasilan dalam pekerjaan yang ditandai dengan perasaan tidak puas terhadap diri sendiri, pekerjaan, bahkan kehidupan.

Variabel eksogen yaitu beban kerja (X) merupakan tuntutan pekerjaan yang harus dilakukan oleh perawat RSD Mangusada Badung selama suatu periode waktu tertentu. Indikator beban kerja disajikan dalam penelitian Suryadi et al. (2018)yang menggunakan metode National Aeronautics and Space Administration Task Load Index (NASA-TLX) dengan 8 indikator pengukuran. Kebutuhan fisik, yaitu seberapa banyak pekerjaan yang dilakukan membutuhkan aktivitas fisik misalnya mendorong, mengangkat, memutar, dan lain-lain. Kebutuhan mental, merupakan seberapa besar pekerjaan yang dilakukan membutuhkan aktivitas mental dan perseptual misalnya menghitung, mengingat, membandingkan, dan lain-lain. Kebutuhan waktu, yaitu seberapa besar tekanan waktu pada pekerjaan yang dilakukan. Performansi, menunjukkan tingkat keberhasilan dalam pekerjaan. Tingkat frustrasi, yaitu seberapa besar tingkat frustrasi terkait dengan pekerjaan (apakah pekerjaan menyebalkan, penuh stres, dan tidak memotivasi, ataukah sebaliknya, menyenangkan, santai, dan memuaskan).

Stres kerja adalah lelah emosional atau perasaan tertekan baik secara fisik maupun psikologis yang dialami oleh perawat RSD Mangusada Badung. Penelitian Sintyadewi \& Dewi (2020) menjelaskan terdapat delapan indikator. Tekanan dalam pekerjaan, yaitu menggambarkan perasaan tertekan saat melakukan pekerjaan. Kesulitan dalam pekerjaan, yaitu menggambarkan perasaan kesulitan saat melakukan pekerjaan. Indikator ini diukur dari tanggapan seseorang yang sering mengeluh kesulitan tidur akibat pekerjaan selama diperusahaan terasa sulit. Pekerjaan membuat individu gelisah, yaitu menggambarkan keadaan yang merasakan kegelisahan saat bekerja di suatu perusahaan dikarenakan target yang harus dipenuhi. Indikator ini diukur dari tanggapan seseorang bahwa pekerjaannya 
sering membuat gelisah. Kelelahan saat bekerja, yaitu menggambarkan keadaan seseorang yang merasa lelah saat melakukan pekerjaan. Indikator ini diukur dari tanggapan seseorang yang sering merasa lelah setelah bekerja setiap hari. Membantu kesehatan apabila merubah pekerjaan, yaitu menggambarkan bagaimana pemikiran seseorang terhadap pekerjaan yang membuat kesehatannya memburuk. Indikator ini diukur dari tanggapan apabila seseorang berganti pekerjaan akan sangat membantu kesehatannya. Lemah saat bekerja, yaitu menggambarkan keadaan seseorang yang merasa tidak mampu menyelesaikan pekerjaannya. Indikator ini diukur dari tanggapan seseorang yang sering merasa lemah saat bekerja. Emosional dalam bekerja, yaitu menggambarkan keadaan seseorang yang tidak dapat mengontrol emosi dalam bekerja dikarenakan mengalami tekanan dalam bekerja. Indikator ini diukur dari tanggapan seseorang yang sering merasa lebih emosional di tempat bekerja. Tidak bahagia di tempat kerja, yaitu menggambarkan pemikiran seseorang yang merasa tidak menemukan kebahagiaan selama bekerja di perusahaan tersebut. Indikator ini diukur dari tanggapan seseorang yang sering merasa tidak bahagia di tempat kerja.

Jenis data yang digunakan yaitu data kuantitatif dan kualitatif, dengan sumber data primer yakni perawat Ruang Oleg RSD Mangusada Badung, sedangkan sumber data sekunder adalah pihak manajemen RSD Mangusada Badung.Instrumen penelitian menggunakan uji validitas dan reliabilitas. Seluruh perawat yang bertugas di Ruang Oleg RSD Mangusada Badung yang berjumlah 50 orang menjadi populasi dalam penelitian ini. Penentuan sampel penelitian menggunakan teknik sampling jenuh yaitu teknik pengambilan sampel apabila semua anggota populasi dijadikan sampel. Sampel dalam penelitian ini berjumlah 50 perawat. Pengumpulan data dengan teknik wawancara dan penyebaran kuesioner. Wawancara merupakan metode pengumpulan data dengan sistem tanya jawab langsung dengan perawat dari RSD Mangusada Badung terkait kondisi burnout yang dialami. Angket merupakan teknik pengumpulan data dengan cara membagikan daftar pernyataan kepada responden terkait variabel penelitian yaitu burnout. Teknik analisis data yang digunakan dalam penelitian ini adalah analisis jalur, uji sobel, dan uji vaf.

\section{HASIL DAN PEMBAHASAN}

Sebagai jasa pelayanan kesehatan RSD Mangusada Badung dituntut untuk memberikan pelayanan terbaiknya bagi masyarakat, dari kinerja berbagai lapisan staff serta tenaga medis harus menunjukkan kemampuan yang optimal dalam melayani masyarakat maupun menangani setiap keluhan pasien. Namun dalam melaksanakan tugas, khususnya tenaga medis yakni perawat, dihadapkan pada berbagai beban dan tantangan dalam bekerja yang tak jarang menimbulkan kejenuhan dan kelelahan kerja yang akan menimbulkan turunnya kualitas pelayanan. Menurunnya kualitas pelayanan bukan hanya karena faktor menurunnya kemampuan tenaga kerja, melainkan karena tingginya beban kerja yang berakibat perawat menjadi letih secara fisik dan mental. Perubahan sosial baru-baru ini mungkin telah berkontribusi pada peningkatan kelelahan dalam profesi kesehatan, dimana kelelahan kerja di antara profesional tenaga kesehatan adalah masalah 
serius dan semakin meningkat.

Responden penelitian ini adalah seluruh perawat di Ruang Oleg RSD Mangusada Badung. Ada 50 kuesioner yang disebarkan dalam penelitian ini, 50 kuesioner dikembalikan dalam penelitian ini. Berdasarkan Tabel 2, karakteristik jenis kelamin menunjukkan bahwa perawat di Ruang Oleg RSD Mangusada Badung yang menjadi responden dalam penelitian ini didominasi oleh perempuan dibandingkan laki-laki. Hal ini dikarenakan perawat perempuan dinilai lebih teliti dengan berbagai prosedur operasional penanganan pasien, serta telaten dalam merawat pasien. Berdasarkan karakteristik menurut usia sebagian besar perawat adalah 31 sampai 35 tahun. Rumah Sakit membutuhkan perawat yang memiliki kemampuan mumpuni dan matang dalam memberikan pelayanan dengan berbagai jenis keluhan pasien, sehingga perawat tidak akan ragu atau bingung dalam menangani pasien, kisaran umur 31 sampai 35 tahun dirasa pas untuk posisi tersebut. Perawat dengan masa kerja 6 sampai dengan 10 tahun lebih mendominasi yaitu sebesar 50 persen karena pada kisaran masa kerja tersebut perawat dinilai sudah memiliki pengalaman dan wawasan yang luas dalam menangani dan melayani berbagai pasien. Profil responden yang terdapat dalam kuesioner terdiri dari jenis kelamin, usia, jabatan, serta masa kerja.

Tabel 2.

Karakteristik Responden

\begin{tabular}{cccc}
\hline \multirow{2}{*}{ Kriteria } & Kategori & Jumlah & Persentase \\
\hline Jenis & Laki-Laki & 9 & 18 \\
Kelamin & Perempuan & 41 & $\mathbf{8 2}$ \\
\hline & Total & 50 & 100 \\
\hline \multirow{3}{*}{ Usia } & 23-30 Tahun & 13 & 26 \\
& 31-35 Tahun & 18 & $\mathbf{3 6}$ \\
& 36-40 Tahun & 12 & 24 \\
& $>40$ Tahun & 7 & 14 \\
\hline \multirow{2}{*}{ Jabatan } & Total & 50 & 100 \\
& Kepala Ruangan & 1 & 2 \\
& Perawat & 49 & $\mathbf{9 8}$ \\
\hline \multirow{3}{*}{ Masa kerja } & Total & 50 & 100 \\
& $1-5$ & 11 & 22 \\
& $6-10$ & 25 & $\mathbf{5 0}$ \\
\hline & $11-15$ & 12 & 24 \\
\hline
\end{tabular}

Sumber: Data diolah, 2020

Berdasarkan hasil karakteristik menurut masa kerja, perawat yang bermasa kerja 6 sampai 10 tahun lebih mendominasi yaitu sebesar 50 persen karena pada kisaran masa kerja tersebut perawat dinilai sudah memiliki pengalaman dan wawasan yang luas dalam menangani dan melayani berbagai pasien. Pengujian validitas dilakukan dengan mengukur korelasi antara skor item instrumen dalam suatu faktor dengan skor total. Jika korelasi masing-masing faktor ini positif dan 
besarnya lebih dari 0,3 , maka faktor tersebut merupakan konstruk yang kuat (Sugiyono, 2018). Dari analisis faktor dapat disimpulkan bahwa instrumen memiliki validitas konstruksi yang baik. Tabel 3. menyajikan hasil uji validitas instrumen penelitian.

Tabel 3.

Hasil Uji Validitas

\begin{tabular}{|c|c|c|c|c|}
\hline No. & Variabel & Instrumen & $\begin{array}{l}\text { Pearson's } \\
\text { Correlation }\end{array}$ & Keterangan \\
\hline \multirow{5}{*}{1.} & \multirow{5}{*}{ Beban Kerja } & $\mathrm{X} 1$ & 0,767 & Valid \\
\hline & & $\mathrm{X} 2$ & 0,831 & Valid \\
\hline & & $\mathrm{X} 3$ & 0,891 & Valid \\
\hline & & $\mathrm{X} 4$ & 0,879 & Valid \\
\hline & & X5 & 0,920 & Valid \\
\hline \multirow{8}{*}{2.} & \multirow{8}{*}{ Stres Kerja } & M1 & 0,897 & Valid \\
\hline & & M2 & 0,894 & Valid \\
\hline & & M3 & 0,861 & Valid \\
\hline & & M4 & 0,941 & Valid \\
\hline & & M5 & 0,798 & Valid \\
\hline & & M6 & 0,910 & Valid \\
\hline & & M7 & 0,856 & Valid \\
\hline & & M8 & 0,875 & Valid \\
\hline \multirow{20}{*}{3.} & \multirow{20}{*}{ Burnout } & Y1.1 & 0,901 & Valid \\
\hline & & Y1.2 & 0,904 & Valid \\
\hline & & Y1.3 & 0,886 & Valid \\
\hline & & Y1.4 & 0,861 & Valid \\
\hline & & Y1.5 & 0,954 & Valid \\
\hline & & Y1.6 & 0,795 & Valid \\
\hline & & Y 1.7 & 0,914 & Valid \\
\hline & & Y2.1 & 0,854 & Valid \\
\hline & & Y2.2 & 0,917 & Valid \\
\hline & & Y2.3 & 0,805 & Valid \\
\hline & & Y2.4 & 0,897 & Valid \\
\hline & & Y2.5 & 0,796 & Valid \\
\hline & & Y2.6 & 0,717 & Valid \\
\hline & & Y 2.7 & 0,863 & Valid \\
\hline & & Y 2.8 & 0,871 & Valid \\
\hline & & Y3.1 & 0,934 & Valid \\
\hline & & Y3.2 & 0,848 & Valid \\
\hline & & Y3.3 & 0,935 & Valid \\
\hline & & Y3.4 & 0,789 & Valid \\
\hline & & Y3.5 & 0,924 & Valid \\
\hline
\end{tabular}

Sumber: Data Diolah 2020

Berdasarkan Tabel 3. terlihat semua instrumen variabel penelitian merupakan beban kerja, stres kerja, dan burnout yang sudah dikatan valid karena menunjukkan total skor diatas 0,30 yang artinya seluruh instrumen layak digunakan sebagai alat ukur variabel tersebut. Nilai reliabilitas ditunjukkan dengan skor Cronbach's Alpha jika skor diatas 0,60 maka instrumen dikatakan reliabel (Sugiyono, 2018). Hasil 
penelitian uji reliabilitas dapat dilihat pada Tabel 4.

Tabel 4.

Hasil Uji Reliabilitas

\begin{tabular}{|c|c|c|c|}
\hline No. & Variabel & Cronbach's Alpha & Keterangan \\
\hline 1. & Beban Kerja & 0,909 & Reliabel \\
\hline 3. & Stres Kerja & 0,957 & Reliabel \\
\hline 4. & Burnout & 0,980 & Reliabel \\
\hline
\end{tabular}

Sumber: Data diolah 2020

Tabel 4. menunjukkan nilai Cronbach's Alpha yang masing-masing variabelnya berada diatas 0,60 , maka dari itu seluruh instrumen telah memenuhi persyaratan reliabilitas.

Analisis jalur (path analysis) adalah perluasan dari analisis regresi linier berganda, dimana pengembangan disini berupa penerapan variabel mediasi. Variabel mediasi merupakan variabel yang memiliki peran memediasi hubungan antara suatu variabel dengan variabel lainnya. Analisis jalur hanya dapat digunakan apabila telah memenuhi asumsi-asumsi tertentu. Pada penelitian ini digunakan analisis jalur (path analysis) dalam melihat pengaruh hubungan kausalistik masingmasing variabel bebas yang terdiri dari beban kerja terhadap variabel terikat yang terdiri dari stres kerja dan burnout. Penelitian ini juga menguji peran variabel mediasi yaitu stres kerja dalam memediasi hubungan antara variabel beban kerja terhadap burnout. Terdapat dua persamaan struktural atau sistem persamaan simultan, dimana hasil pengolahan data menggunakan SPSS. Hasil data menggunakan SPSS, model persamaan struktural untuk struktur pertama menunjukkan hasil sebagai berikut.

Tabel 5.

Hasil Analisis Jalur Pada Struktur 1

\begin{tabular}{|c|c|c|c|c|c|}
\hline \multirow[t]{2}{*}{ Model } & \multicolumn{2}{|c|}{ Unstandardized Coefficients } & \multirow{2}{*}{$\begin{array}{c}\begin{array}{c}\text { Standardized } \\
\text { Coefficients }\end{array} \\
\text { Beta }\end{array}$} & \multirow[t]{2}{*}{$\mathbf{t}$} & \multirow[t]{2}{*}{ Sig. } \\
\hline & B & Std. Error & & & \\
\hline (Constant) & 0,486 & 0,297 & & 1,637 & 0,108 \\
\hline Beban Kerja & 0,878 & 0,071 & 0,873 & 12,386 & 0,000 \\
\hline $\begin{array}{ll}\mathrm{R}^{2} & : 0,762\end{array}$ & & & & & \\
\hline
\end{tabular}

$$
\begin{array}{ll}
\mathrm{Z} & =0,873 \mathrm{X} \\
\mathrm{Std} \text { Er } & =(0,071) \\
\mathrm{T} & =(12,386) \\
\text { Sig. } & =(0.000) \\
\mathrm{R}^{2} & =0,762
\end{array}
$$

Nilai koefisien regresi variabel beban kerja bernilai positif dengan nilai 
signifikansi uji t kurang dari 0,05. Hal ini menunjukkan bahwa variabel beban kerja memiliki pengaruh positif yang signifikan terhadap stres kerja. Besarnya pengaruh tersebut ditunjukkan oleh nilai determinasi total ( $\mathrm{R}$ Square) sebesar 0,762 mempunyai arti bahwa sebesar 76,2\% variabel stres kerja dipengaruhi oleh variabel beban kerja, sedangkan sisanya sebesar $23,8 \%$ dijelaskan oleh faktor lain yang tidak dimasukan dalam model.

Tabel 6.

Hasil Analisis Jalur Pada Struktur 2

\begin{tabular}{|c|c|c|c|c|c|}
\hline \multirow{2}{*}{ Model } & \multicolumn{2}{|c|}{$\begin{array}{c}\text { Unstandardized } \\
\text { Coefficients }\end{array}$} & \multirow{2}{*}{$\begin{array}{c}\begin{array}{c}\text { Standardized } \\
\text { Coefficients }\end{array} \\
\text { Beta }\end{array}$} & \multirow[t]{2}{*}{$\mathbf{t}$} & \multirow[t]{2}{*}{ Sig. } \\
\hline & $\mathrm{B}$ & Std. Error & & & \\
\hline (Constant) & $-0,042$ & 0,112 & & $-0,371$ & 0,713 \\
\hline Beban Kerja & 0,461 & 0,053 & 0,466 & 8,629 & 0,000 \\
\hline Stres Kerja & 0,542 & 0,053 & 0,551 & 10,205 & 0,000 \\
\hline
\end{tabular}

Sumber: Data Diolah 2020 berikut :

Hasil persamaan struktural untuk struktur kedua, menunjukkan hasil sebagai

$\mathrm{Y}=0,466 \mathrm{X}+0,551 \mathrm{Z}$

Std. Er = $(0,053)(0,053)$

$\mathrm{T}=(8,629)(10,205)$

Sig $=(0,000)(0,000)$

$\mathrm{R}^{2} \quad=0,967$

Nilai koefisien regresi masing-masing variabel bebas bernilai positif dengan nilai signifikansi uji t kurang dari 0,05 . Hal ini menunjukkan bahwa semua variabel bebas memiliki pengaruh positif terhadap variabel terikat. Besarnya pengaruh variabel bebas terhadap variabel terikat yang ditunjukkan oleh nilai determinasi total (R Square) sebesar 0,967 mempunyai arti bahwa sebesar 96,7\% variabel burnout dipengaruhi oleh beban kerja dan stres kerja, sedangkan sisanya sebesar 3,3\% dijelaskan oleh faktor lain yang tidak dimasukkan ke dalam model.

Hasil pengujian pengaruh variabel stres kerja (Z) terhadap kelelahan (Y) menjelaskan bahwa stres kerja berpengaruh positif signifikan terhadap kelelahan dengan nilai koefisien standar beta 0,466 dan nilai sig t 0,000, hal ini berarti $\mathrm{H} 1$ diterima. Keluaran dari hasil SPSS pengujian pengaruh variabel beban kerja (X) terhadap burnout $(\mathrm{Y})$ dengan mediasi stres kerja $(\mathrm{Z})$ diilustrasikan dengan model diagram jalur seperti pada Gambar 2.

Berdasarkan informasi pada Gambar 2. diketahui bahwa koefisien jalur pengaruh beban kerja terhadap variabel burnout setelah variabel stres kerja dimasukkan ke dalam model adalah 0,466, artinya stres kerja memediasi pengaruh positif beban kerja terhadap kelelahan kerja (burnout) perawat di Ruang Oleg RSD Mangusada Badung. Perhitungan hasil pengaruh error (Pe1) sebesar 0,878 dan 
pengaruh error ( $\mathrm{Pe} 2)$ sebesar 0,461 dengan nilai determinasi total 0,937 artinya 93,7\% variasi burnout dipengaruhi oleh variabel beban kerja dan stres kerja, sedangkan 6,3 persen sisanya dijelaskan oleh faktor lain yang tidak termasuk dalam model.

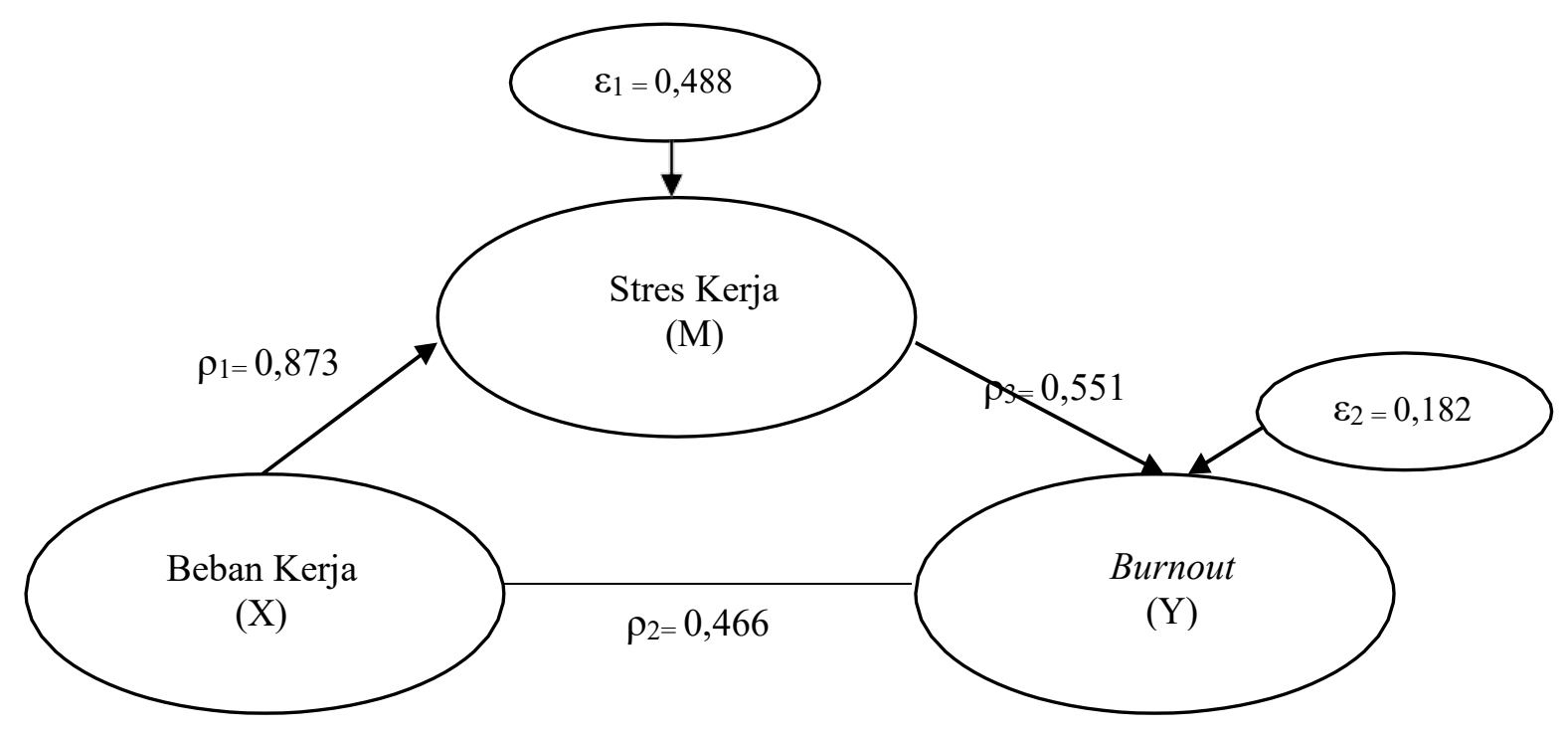

\section{Gambar 2. Validasi Model Diagram Jalur Akhir}

Uji sobel merupakan alat analisis untuk menguji signifikansi dari hubungan tidak langsung antara variabel independen dengan variabel dependen yang dimediasi oleh variabel mediator. Uji Sobel dirumuskan dengan persamaan berikut dan bila nilai kalkulasi $\mathrm{Z}$ lebih besar dari 1,96 (dengan tingkat kepercayaan 95 persen), maka variabel mediator dinilai secara signifikan memediasi hubungan antara variabel terikat dan variabel bebas. Dalam hal ini menguji pengaruh beban kerja terhadap burnout melalui stres kerja. Stres kerja merupakan mediator hubungan dari beban kerja ke burnout. Untuk menguji seberapa besar peran stres kerja memediasi pengaruh beban kerja terhadap burnout digunakan uji Sobel.

Uji sobel dihitung dengan rumus :

$$
\begin{aligned}
& Z=\frac{a b}{\sqrt{b^{2}} s_{a}^{2}+a^{2} s_{b}^{2}+s_{a}^{2} s_{b}^{2}} \ldots \ldots \ldots \ldots \ldots \ldots \ldots .(1) \\
& Z=\frac{0,878.0,542}{\sqrt{(0,542)^{2}(0,071)^{2}+(0,878)^{2}(0,053)^{2}+(0,071)^{2}(0,053)^{2}}}
\end{aligned}
$$




$$
Z=\frac{0,4758}{0,0617}
$$

$$
\mathrm{Z}=\mathbf{7 , 7 1 1}
$$

Setelah didapatkan hasil melalui analisis jalur, didukung juga dengan hasil perhitungan uji sobel yang mendapatkan nilai z hitung sebesar 7,711, karena nilai $\mathrm{z}$ hitung yang diperoleh sebesar 7,711 >1,96 ( $\mathrm{z}$ tabel) dengan tingkat signifikansi $5 \%$ maka membuktikan bahwa stres kerja mampu memediasi hubungan pengaruh beban kerja terhadap burnout.

Uji VAF menjadi ukuran seberapa besar variabel pemediasi mampu menyerap pengaruh langsung yang sebelumnya signifikan dari model tanpa pemediasi. Apabila nilai VAF di atas 80 persen, maka menunjukkan peran stres kerja sebagai pemediasi penuh (full mediation). Selanjutnya apabila nilai VAF di antara 20 persen hingga 80 persen, maka dapat dikategorikan sebagai pemediasi persial (partial mediation). Namun, apabila nilai VAF kurang dari 20 persen, maka dapat dijelaskan bahwa hampir tidak ada efek mediasi.

Hasil uji VAF didapatkan hasil sebagai berikut :

$$
\begin{aligned}
\mathrm{VAF} & =(\mathrm{b} \times \mathrm{c}) /(\mathrm{a}+\mathrm{b} \times \mathrm{c}) \ldots \ldots \ldots \ldots \ldots \ldots(2) \\
& =(0,878 \times 0,542) /(0,947+0,878 \times 0,542) \\
& =0,476 / 1,423 \\
& =0,3345 \text { atau } 33,45 \text { persen }
\end{aligned}
$$

Karena nillai VAF sebesar 33,45 persen yang dimana lebih dari 20 persen, maka dapat disimpulkan bahwa stres kerja dikategorikan sebagai pemediasi parsial (partial mediation).

Hasil penelitian menyatakan bahwa beban kerja berpengaruh positif dan signifikan terhadap burnout, dimana jika pihak RSD Mangusada Badung khususnya Ruang Oleg ingin menurunkan tingkat burnout perawat, maka harus memperhatikan indikator yang membuat perawat tidak membawa beban kerja yang tinggi seperti berapa banyak. aktivitas fisik yang melebihi kapasitas perawat dalam melaksanakan tugas, seberapa banyak pekerjaan yang membutuhkan kekuatan mental, seberapa besar tekanan waktu pada pekerjaan yang dilakukan, seberapa puas tingkat kinerja yang telah dicapai, dan seberapa besar tingkat frustrasinya. dengan pekerjaan itu.

Beban kerja berpengaruh positif dan signifikan terhadap stres kerja. Artinya semakin tinggi beban kerja perawat dalam bekerja maka semakin tinggi pula stres kerjanya. Stres kerja berpengaruh positif dan signifikan terhadap burnout pada perawat, sehingga menunjukkan semakin tinggi perawat mengalami stres kerja maka semakin tinggi pula kemungkinan perawat mengalami burnout. Rumah sakit harus memperhatikan kondisi mental perawat agar tidak menimbulkan stres kerja 
yang berkepanjangan. Stres kerja yang dialami perawat dalam jangka waktu lama akan menyebabkan kejenuhan. Beban kerja yang berlebih diluar kemampuan seseorang menyebabkan timbulnya kecemasan, perasaan tertekan, selalu merasa bersalah terhadap sesuatu yang terjadi, bahkan sampai mengakibatkan metabolisme pada tubuh terganggu. Kondisi ini membuat seseorang menjadi tidak memiliki minat dan ketertarikan terhadap pekerjaan yang dilakukannya, hal ini menekankan penyebab terjadinya stres kerja pada seseorang karena tekanan atau beban pekerjaan yang besar, sehingga seseorang merasa tidak senang dan kurang nyaman dalam menyelesaikan pekerjaannya.

Stres kerja memiliki pengaruh positif dan signifikan terhadap burnout. Kondisi ini menandakan bahwa semakin tinggi stres kerja yang dihadapi para perawat di Ruang Oleg RSD Mangusada Badung maka semakin tinggi kemungkinan seorang perawat mengalami burnout. Hal ini juga menjelaskan stres kerja berpengaruh positif dan signifikan terhadap burnout. Ketika seseorang merasa tidak cocok dengan pekerjaan dan tertekan dengan pekerjaannya maka secara tidak langsung menimbulkan stres kerja, kondisi ini mengakibatkan ketidakberdayaan seseorang dan akhirnya menimbulkan sindrom kelelahan kerja atau yang disebut juga burnout

Stres kerja mampu memediasi pengaruh beban kerja terhadap burnout secara positif dan signifikan, kondisi ini berarti semakin tinggi tingkat stres kerja yang dialami perawat maka semakin tinggi pula beban kerja yang diemban, sehingga kemungkinan besar terjadi perawat yang mengalami burnout lebih tinggi. Penelitian ini mendukung dan memperjelas hubungan antara beban kerja, stres kerja, dan variabel burnout. RSD Mangusada dalam meminimalisir burnout yang dialami perawat harus memperhatikan beban kerja dan tingkat stres kerja perawat serta disesuaikan dengan apa yang telah ditentukan oleh manajemen rumah sakit dan memperhatikan kapasitas masing-masing perawat dalam memberikan pekerjaan dan aktivitas yang dapat menimbulkan dampak fisik dan fisik. beban fisik. perawat jiwa, karena hal tersebut akan mempengaruhi kualitas pelayanan di RSD Mangusada Badung.

Penelitian ini diharapkan akan memberikan kontribusi positif bagi semua pihak khususnya perawat dan RSD Mangusada Badung. Bagi perawat hendaknya tetap menjaga kondisi fisik maupun psikis dalam kesehariannya menjalankan pekerjaan, serta penting bagi perawat untuk memiliki kondisi tubuh dan mental yang sehat, karena merupakan suatu kepuasan tersendiri bagi perawat jika mampu menunjukkan kondisi yang maksimal bukan hanya bagi diri sendiri tetapi akan berdampak kepada hasil pelayanan terhadap pasien juga. Bagi pihak RSD Mangusada dalam meminimalisir burnout yang dialami perawat sebaiknya memperhatikan beban kerja dan tingkat stres kerja perawat dengan baik dan disesuaikan dengan apa yang telah ditetapkan manajemen rumah sakit serta memperhatikan kapasitas masing-masing perawat dalam memberikan pekerjaan maupun kegiatan yang sekiranya dapat menyebabkan beban bagi fisik dan mental perawat, karena hal-hal tersebut akan mempengaruhi kualitas pelayanan RSD Mangusada Badung.

\section{SIMPULAN}


Beban kerja berpengaruh positif dan signifikan terhadap stres kerja perawat di Ruang Oleg RSD Mangusada Badung. Beban kerja berpengaruh positif dan signifikan terhadap burnout perawat di Ruang Oleg RSD Mangusada Badung, semakin tinggi beban kerja perawat maka semakin tinggi tingkat burnout yang dialami perawat. Stres berpengaruh positif dan signifikan terhadap burnout perawat kerja. di Ruang Oleg RSD Mangusada Badung, jika stres kerja semakin tinggi maka secara langsung dapat menyebabkanlebih tinggi. kelelahan perawat yang stres merupakan variabel mediasi pengaruh beban kerja terhadap kelelahan kerja perawat di Ruang Oleg RSD Mangusada Badung, dimana pengaruh variabel beban kerja terhadap variabel stres kerja signifikan dan pengaruh variabel stres kerja terhadap variabel burnout juga signifikan, sehingga dapat dikatakan bahwa hasil penelitian ini mendukung pengaruh mediasi secara parsial. Semakin tinggi beban kerja yang dihadapi perawat maka semakin tinggi stres kerja yang dialaminya yang pada akhirnya menyebabkan meningkatnya burnout.

Hasil penelitian pada variabel beban kerja ditemukan masalah utama yang dialami yakni perawat membutuhkan usaha mental yang kuat untuk menyelesaikan pekerjaan. Hal tersebut menandakan bahwa perawat memerlukan mental yang kuat dalam menghadapi beban pekerjaan, kondisi ini menyebabkan beban kerja yang tinggi pula. Pihak rumah sakit disarankan untuk lebih menanggulangi beban mental yang dialami oleh perawat dengan memperhatikan pembagian tugas yang diberikan. Pembagian tugas juga harus diimbangi dengan proporsi waktu yang sesuai dengan kemampuan perawat. Hal ini harus didukung dengan memperhatikan lingkungan kerja yang baik, sehingga kondisi ini dapat mendukung perawat dalam bekerja. Hal-hal tersebut diharapkan dapat disesuaikan agar perawat tidak merasa terbebani dan nyaman dalam bekerja.

Hasil penelitian pada variabel stres kerja ditemukan masalah utama yang dialami yakni perawat merasakan kelelahan setelah melakukan pekerjaan setiap hari. Hal tersebut menandakan perawat selalu merasa lelah setiap hari setelah menyelesaikan pekerjaan yang secara tidak langsung akan menimbulkan stres yang tinggi. Pihak rumah sakit disarankan untuk lebih menanggulangi stres kerja yang dialami oleh perawat dengan memperhatikan proporsi waktu dan jumlah perawat yang menangani masing-masing pasien sesuai dengan standar Manajemen Penugasan Klinik Perawat (MPKP) yang menjelaskan satu orang perawat hanya boleh menangangi 6-8 orang pasien. Diharapkan hal tersebut dapat disesuaikan dengan kemampuan perawat dalam bekerja sehingga meminimalisir terjadinya kelelahan kerja. Hasil penelitian pada variabel burnout ditemukan masalah utama yang dialami yakni perawat merasakan kelelahan secara emosional dalam menyelesaikan pekerjaan. Hal tersebut menandakan ketika perawat merasa lelah secara emosional dalam mengerjakan pekerjaannya, maka secara tidak langsung kondisi ini memicu timbulnya burnout. Pihak rumah sakit disarankan untuk menanggulangi burnout yang dialami oleh perawat dengan memperhatikan kemampuan dalam bekerja, standar dalam melayani pasien, dan tidak selalu menekan perawat dengan pekerjaan melainkan memberikan perawat masa libur yang sesuai dan sesekali mengadakan kegiatan outdoor untuk menghilangkan penat.

Bagi penelitian selanjutnya diharapkan mampu menambah variabel- variabel 
yang dapat mempengaruhi burnout, serta mampu untuk memperluas ruang lingkup penelitian yang tidak hanya terbatas pada RSD Mangusada Badung khususnya di Ruang Oleg, atau dapat juga mengganti lokasi penelitian yang tidak hanya terfokus pada satu lokasi penelitian, sehingga memberikan suatu pandangan yang lebih dan mampu diimplementasikan secara umum.

\section{REFERENSI}

Atmaja, I. G. I. W., \& Suana, I. W. (2018). Pengaruh Beban Kerja Terhadap Burnout Dengan Role Stress Sebagai Variabel Mediasi Pada Karyawan Rumours Restaurant. E-Jurnal Manajemen Universitas Udayana, 8(2), 815.

Candra, I., \& Huda, A. N. (2018). Hubungan Antara Stres Kerja Dengan Burnout Pada Wanita Karir Yang Sudah Menikah Di Yayasan Igasar Padang. Jurnal Psikohumanika, 9(1), 15-30.

Chiang, C. F., \& Liu, B. Z. (2017). Examining Job Stress and Burnout of Hotel Room Attendants: Internal Marketing and Organizational Commitment as Moderators. Journal of Human Resources in Hospitality and Tourism, 16(4), 367-383.

Dewi, R. S., \& Riana, I. G. (2019). The Effect of Workload on Role Stress and Burnout. Journal of Multidisciplinary Academic, 03(03).

Eliyana. (2016). Faktor - Faktor yang Berhubungan dengan Burnout Perawat Pelaksana di Ruang Rawat Inap RSJ Provinsi Kalimantan Barat Tahun 2015. Arsi, 2(3), 172-182.

Fajriani, A., \& Septiari, D. (2015). Pengaruh Beban Pekerjaan terhadap Kinerja Karyawan : Efek Mediasi Burnout. Jurnal Akuntansi, Ekonomi Dan Manajemen Bisnis, 3(1), 74-79.

Gnerre, P., Rivetti, C., Rossi, A. P., Tesei, L., Montemurro, D., \& Nardi, R. (2017). Work stress and Burnout among Physicians and Nurses in Internal and Emergency Departments. Italian Journal of Medicine, 11(2), 151-158.

Koc, E., \& Bozkurt, G. A. (2017). Hospitality Employees' Future Expectations: Dissatisfaction, Stress, and Burnout. International Journal of Hospitality and Tourism Administration, 18(4), 459-473.

Kumar, S. (2018). Preventing and Managing Burnout: What have we learned? Biomedical Journal of Scientific \& Technical Reseacrh, 2(1), 2404-2407.

Lan, Y., Lin, Y., Yan, Y.-H., \& Tang, Y.-P. (2018). Relationship Between Work Stress, Workload, and Quality of Life Among Rehabilitation Professionals. International Journal of Healthcare and Medical Sciences, 4(6), 105-110.

Melati, P., Yo, P., Bagus, I., \& Surya, K. (2015). Pengaruh Beban Kerja Terhadap Kepuasan Kerja Dengan Stres Kerja Sebagai Variabel Mediasi. E-Jurnal 
Manajemen Universitas Udayana, 4(5), 1149-1165.

Moch, S. (2014). Stres Kerja Terhadap Burnout Serta Implikasinya Pada Kinerja. Jurnal Manajemen Dan Akuntansi, 3(02), 52-63.

Pesireron, S. (2016). Pengaruh Keterampilan, Job Stress dan Disiplin Kerja Terhadap Kinerja Auditor Inspektorat. Jurnal Maneksi, 5(1), 26-31.

Pradana, B. A., Kristanto, R. S., \& Hidayat, D. S. (2017). Pengaruh Lingkungan Kerja Dan Beban Kerja Terhadap Burnout Pada Perawat Rsud Kardinah Kota Tegal. Jurnal Magisma, 5(2), 61-70.

Robbins, S. (2008). Perilaku Organisasi (H. Pujaatmaja (ed.); Jilid I da). Prenhallindo.

Rubab, U. (2017). Impact of Work Family Conflict on Burnout and Workplace Deviant Behavior: Mediating Role of Stress. Jinnah Business Review, 5(1), $1-10$.

Saputro, R., Aima, M. H., \& Elmi, F. (2020). Effect Of Work Stress And Work Load On Burnout And Its Implementation In Turnover Intention Erha Clinic Branch Office (Bogor, Depok And Mangga Besar). Dinasti International Journal of Management Science, 1(2), 191-203.

Sintyadewi, N. P. M. N., \& Dewi, I. G. A. M. (2020). Peran Burnout Memediasi Pengaruh Stres Kerja Terhadap Turnover Intention Karyawan Kutabex Beach Front Hotel Bali. E-Jurnal Manajemen Universitas Udayana, 9(6), 2308-2331.

Sugiyono. (2016). Metode Penelitian Pendidikan Pendekatan Kuantitaif, Kualitatif, dan $R \& D$. Alfabeta.

Suryadi, A., Zadi, F. I., \& Sukma, D. (2018). Analisis Tingkat Beban Kerja Operator Automated Stacking Crane ( Asc ) Dengan Metode Nasa-Tlx ( National Aeronautics \& Space Administration Task Load Index ) Di Pt . Terminal Teluk Lamong Surabaya. Journal of Industrial Engineering and Management, 13(02), 32-40.

Wati, H., Abdullah, R., \& Tamsah, H. (2016). Pengaruh Konflik Peran Ganda, Beban Kerja dan Kelelahan Kerja (Burnout) Dengan Kinerja Perawat Wanita Di RSUD I Lagaligo Kabupaten Luwu Timur. Jurnal Mirai Management, Vol. 1(No. 1), 119-135.

Widyastuti, N. (2015). Pengaruh Stres Kerja dan Beban Kerja terhadap Kinerja SKPD Kabupaten Sintang Kalimantan Barat. Jurnal Maksipreneur: Manajemen, Koperasi, Dan Entrepreneurship, 4(2), 15.

Wijaya, I. M., \& Wibawa, I. M. (2020). Beban Kerja Berpengaruh Terhadap Burnout dengan Variabel Work Family Conflict Sebagai Pemediasi. E-Jurnal 
Putu Meliantha Kusumawati, Peran Stres Kerja...

Manajemen Universitas Udayana, 9(2), 597-616.

Ziaei, M., Yarmohammadi, H., Moradi, M., \& Khandan, M. (2015). Level of Workload and Its Relationship with Job Burnout among Administrative Staff. International Journal of Occupational Hygiene, 53-60. 